\title{
The case method: study of a corrosion problem
}

\author{
María José Muñoz-Portero ${ }^{a}$, Rita Sánchez-Tovar ${ }^{b}$, Ramón Manuel Fernández- \\ Domene $^{c}$ \\ Departamento de Ingeniería Química y Nuclear, Escuela Técnica Superior de Ingenieros Industriales, \\ a(Universitat Politècnica de València, Valencia, Spain, mjmunoz@iqn.upv.es), \\ ${ }^{\mathrm{b}}$ (Universitat Politècnica de València, Valencia, Spain, risanto@etsii.upv.es), \\ ${ }^{\mathrm{c}}$ (Universitat Politècnica de València, Valencia, Spain, raferdo1@etsii.upv.es). \\ ${ }^{a, b}$ Equipo de Innovación y Calidad Educativa sobre Trabajo y Evaluación de Asignaturas mediante \\ Técnicas de Evaluación Continua Formativa (EICE-TECOF).
}

\section{Abstract}

The aim of the present work is the application of the case method as teaching-learning methodology for the study of a corrosion problem, in order to obtain more active learning of the student. The educational innovation has been applied in 2018/2019 academic year in the subject of "Manufacturing Processes of Building Materials" imparted in the fourth course of the Chemical Engineering Degree in the Higher Technical School of Industrial Engineering in the Polytechnic University of Valencia. Such educational innovation consists in the description by the lecturer of a real situation about a corrosion problem, so that the students can analyse it and propose solutions individually and in group. At the end of the case it is added questions to help to the students in the analysis. This activity is realized in class, which is evaluated using a rubric. The evaluation of the educational innovation proposed is realized by the scores of the students, the polls of the students, and the autoevaluation of the lecturer. The results show the high scores obtained by the students in the case method and the high grade of satisfaction of the students after applying the educational innovation. The case method permits that the students know real situations that they could find in a professional future, which increase the motivation towards the subject of study.

Keywords: case method, corrosion, real situation, rubric. 


\section{Introduction}

The case method is part of a group of teaching methodologies called "active" due to the role of the student in the teaching-learning process (Bain, 2005).

The origin of the case method dates back to 1870 when Christopher Columbus Langdell introduced it to the Law School of the University of Harvard, substituting textbook reading for case reading. In that way, law students learned the laws facing real situations in which they had to make decisions, base resolutions, and evaluate actions. In the year 1914 the case is formalized as a method of teaching in the program of law under the term of "Case System". Due to its success the method of the case was extended to other disciplines such as business schools, medicine, psychology, political science, social sciences, etc., and in the last decades it has begun to be used in technical areas (Vázquez, 1995).

The method of the case consists in the description by the teacher of a real situation from which a problem to be solved is proposed so that the students can analyze it and propose solutions, favoring in that way the reflection and the learning of the students (Wassermann, 1994).

The description of the case should be clear, easy to read and with adequate terminology. It is advisable to add questions at the end to help the student in the analysis (Labrador, 2008).

The case method consists of several stages (López, 1997):

- Preliminary phase: reading and case study individually for the taking of consciousness.

- Phase of expression of opinions and judgments: reflection and search for answers to questions in an individual way.

- Contrast phase: pooling of analyzed data and responses in small groups. Subsequently, it is done the joint in the whole group. At the end of this stage the teacher can make the synthesis and express his own reflections and opinions on the problem that raises the case.

- Theoretical reflection phase: formulation of theoretical concepts derived from the case in small groups.

The benefits derived from the application of the case method for educational purposes in higher education are (Labrador, 2008):

- Encourages the student's active participation.

- It is based on real situations that the student will be able to find in a professional future, which increases the motivation towards the subject of study. 
- It encourages students to work individually and then contrast their reflections with other partners, facilitating meaningful learning.

The aim of the present work is the application of the case method as teaching-learning methodology for the study of a corrosion problem, in order to obtain more active learning of the student.

\section{Methodology}

\subsection{Context}

The context of the subject in which the case method is applied corresponds to the subject of "Manufacturing Processes of Building Materials", taught in the 4th year of the Degree in Chemical Engineering at the Higher Technical School of Industrial Engineers (ETSII) of the Polytechnic University of Valencia (UPV). This is an optional subject of the subject "Mentions-ETSII (Industrial Processes)" within the "Itineraries" module. The subject is taught in semester B and it consists of 4.5 credits $(2.5$ credits of theory, 1.1 credits of classroom practices, 0.6 credits of field practices, and 0.3 credits of laboratory practices). Three general and specific competences are expected to be achieved by the students in the subject: 1) design processes in the different industrial activities in the field of chemical engineering (specific competence), 2) make decisions and reason critically (general competence), and 3) design equipment, installations, and services in the chemical industry (specific competence). The transversal competence of "understanding and integration" is developed and evaluated in the subject, which is check point. The number of students enrolled in the 2018-2019 academic year was 15. The fact of having a small number of students can facilitate the development and evaluation of the case method.

The context of the case method within the subject corresponds to topic 6 of "Processing of steel" within the didactic unit 3 on "Manufacturing processes of metallic materials used in construction". The objective of this topic is that the student knows the manufacturing processes of iron and steel and their applications in construction.

\subsection{Design of the activity}

The teaching objective of the case method is that the student knows one of the contemporary problems that can arise in the applications of steel in construction: the corrosion of steel. For this, the student must be able to: 
- Identify the problem of steel corrosion, specifically the corrosion produced by chlorides in marine environments, analyzing their causes and consequences.

- Propose alternative solutions to avoid corrosion, relating them to existing solutions.

\subsection{Development of the activity}

The case method is carried out within the credits of classroom practices of the subject. To do this, once the explanation of topic 6 on "Processing of steel" is finished, the case method is proposed as an activity to be carried out in class. The duration of the activity in the classroom will be one hour. It is divided in two parts. In the first part, the students are organized in groups of 2-3 people. Students are given the statement of the case. Some time is left in class for the students to read the case carefully and then each group answers the questions proposed. At the end of the class each group gives the task to the teacher. The duration of the first part is about half an hour. The second part of the activity is realized at the beginning of the following class for half an hour. The teacher gives the students the corrected tasks. The answers are shared in the whole group. At the end of this part the teacher makes a synthesis of the activity.

\subsection{Evaluation of the activity}

The evaluation of the activity is carried out by the teacher based on the task delivered in a group manner through a rubric prepared with iRubric (Table 1). Students have the rubric of evaluation during the development of the activity to be able to know previously the criteria with which they are going to be evaluated.

The rubric of evaluation of the case method consists of 4 indicators, which are evaluated with a scale of 0 to 3: not reached (0), in development (1), good/adequate (2), and excellent/exemplary (3). The evidences of the students to be able to perform the evaluation of the activity are:

- Indicator 1: Identify the causes of the problem. Evidence: answer to question 1 of the case.

- Indicator 2: Identify the consequences of the problem. Evidence: answer to question 2 of the case.

- Indicator 3: Reason (criticizes) the solution already proposed for the problem. Evidence: answer to question 3 of the case.

- Indicator 4: Proposes new solutions to the problem. Evidence: answer to question 4 of the case. 
Table 1. Rubric for the evaluation of the case method (author own elaboration).

\begin{tabular}{|c|c|c|c|c|}
\hline \multirow{2}{*}{ INDICATORS } & \multicolumn{4}{|c|}{ DESCRIPTORS } \\
\hline & $\begin{array}{l}\text { Not reached } \\
(\mathbf{0})\end{array}$ & $\begin{array}{c}\text { In development } \\
\text { (1) }\end{array}$ & $\begin{array}{c}\text { Good/adequate } \\
\text { (2) }\end{array}$ & $\begin{array}{l}\text { Excellent/exemplary } \\
\text { (3) }\end{array}$ \\
\hline $\begin{array}{l}\text { Identify the causes of the } \\
\text { problem }\end{array}$ & $\begin{array}{l}\text { It does not identify } \\
\text { any cause. }\end{array}$ & $\begin{array}{l}\text { Identify few causes } \\
\text { and do not explain } \\
\text { them. }\end{array}$ & $\begin{array}{l}\text { Identify many } \\
\text { causes and partially } \\
\text { explain them. }\end{array}$ & $\begin{array}{l}\text { Identify many causes } \\
\text { and explain them in } \\
\text { detail. }\end{array}$ \\
\hline $\begin{array}{l}\text { Identify the consequences } \\
\text { of the problem }\end{array}$ & $\begin{array}{l}\text { It does not identify } \\
\text { any consequences. }\end{array}$ & $\begin{array}{l}\text { It identifies few } \\
\text { consequences and } \\
\text { does not explain } \\
\text { them. }\end{array}$ & $\begin{array}{l}\text { It identifies many } \\
\text { consequences and } \\
\text { partially explains } \\
\text { them. }\end{array}$ & $\begin{array}{l}\text { Identify many } \\
\text { consequences and } \\
\text { explain them in detail. }\end{array}$ \\
\hline $\begin{array}{l}\text { Reason (criticizes) the } \\
\text { solution already proposed } \\
\text { for the problem }\end{array}$ & $\begin{array}{l}\text { It does not reason } \\
\text { (criticize) the } \\
\text { proposed solution } \\
\text { or it does it } \\
\text { wrongly. }\end{array}$ & $\begin{array}{l}\text { Reason (criticize) } \\
\text { the proposed } \\
\text { solution } \\
\text { incompletely. }\end{array}$ & $\begin{array}{l}\text { Reason (criticize) } \\
\text { the proposed } \\
\text { solution in an } \\
\text { appropriate way. }\end{array}$ & $\begin{array}{l}\text { Reason (criticize) the } \\
\text { proposed solution and } \\
\text { analyze it } \\
\text { optimally/satisfactorily. }\end{array}$ \\
\hline $\begin{array}{l}\text { Proposes new solutions to } \\
\text { the problem }\end{array}$ & $\begin{array}{l}\text { It does not propose } \\
\text { any new solution. }\end{array}$ & $\begin{array}{l}\text { It proposes some } \\
\text { new solution, but it } \\
\text { does not develop it. }\end{array}$ & $\begin{array}{l}\text { It proposes new } \\
\text { solutions, justifies } \\
\text { them, and develops } \\
\text { them. }\end{array}$ & $\begin{array}{l}\text { It proposes new } \\
\text { solutions, justifies } \\
\text { them, develops them, } \\
\text { and relates them to the } \\
\text { existing solution. }\end{array}$ \\
\hline
\end{tabular}

The teacher gives feedback to the students of the evaluation of the case method.

\section{Results}

The evaluation of the educational innovation proposed is realized by the scores of the students, the opinion polls of the students, and the autoevaluation of the lecturer.

\subsection{Scores of the students}

Table 2 shows the results obtained by the students in the case method realized in class in the subject of "Manufacturing Processes of Building Materials" in the 2018-2019 academic year. The number of students that realizes the activity of the case method is 14 . The students are organized in 6 groups: 2 groups of 3 students and 4 groups of 2 students. The evaluation of the activity is realized for each group. Each box in Table 2 is divided into two parts: on the left side is shown the number of groups who obtains each of the scores and on the right side is shown the percentage of groups. 
The results shown in Table 2 indicate that the students obtain good results in the evaluation of the case method realized in class. For each of the indicators evaluated with the rubric (except for the indicator 1), the highest percentage of groups obtains a score of 2 (good/adequate). There are no students with a score of 0 (not reached). In the case of the indicator 1 , the highest percentage of groups $(67 \%)$ obtains a score of 3 (excellent/exemplary), while $33 \%$ of the groups obtains a score of 2 (good/adequate).

Tabla 2. Scores obtained by the students in the case method realized in class in the subject of "Manufacturing Processes of Building Materials" in the 2018-2019 academic year (author own elaboration).

\begin{tabular}{|c|c|c|c|c|}
\hline \multirow[b]{2}{*}{ Indicator } & \multicolumn{4}{|c|}{ Scores } \\
\hline & 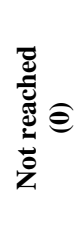 & 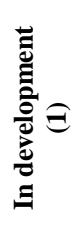 & 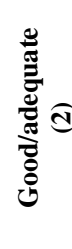 & 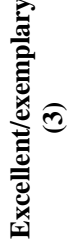 \\
\hline Indicator 1 & & & & \\
\hline Indicator 2 & & & & \\
\hline Indicator 3 & & & & \\
\hline Indicator 4 & & & & \\
\hline
\end{tabular}

Indicator 1: Identify the causes of the problem.

Indicator 2: Identify the consequences of the problem.

Indicator 3: Reason (criticizes) the solution already proposed for the problem.

Indicator 4: Proposes new solutions to the problem.

\subsection{Opinion polls of the students}

Students fill out an opinion poll of the subject the last class day. The opinion poll has two parts. In the first part, the students must fill out a table with the strong points and the weak points about different aspects in the subject. In the second part, the student must assess a total number of 18 items, in a scale of 0 to 10 points, including the case method: very deficient/very low/very inadequate (VD/VL/VI) with 0 points, deficient/low/inadequate 
(D/L/I) with 2.5 points, regular $(\mathrm{R})$ with 5 points, good/high/adequate $(\mathrm{G} / \mathrm{H} / \mathrm{A})$ with 7.5 points, and very good/very high/very adequate (VG/VH/VA) with 10 points.

Fig. 1 shows the results of the opinion poll of the students about the case method realized in class in the subject of "Manufacturing Processes of Building Materials" in the 2018-2019 academic year. The total number of opinion poll processed is 15 (100\% of the registered students). According with the results obtained, the majority of the students considering the case method realized in class as very adequate ( 7 students, being the $47 \%$ of the polled students). The other students considering the case method as adequate ( 5 students, being the $33 \%$ of the polled students) and regular ( 2 students, being the $13 \%$ of the polled students). Only 1 student ( $7 \%$ of the polled students) indicates do not know/no answer (NK/NA).

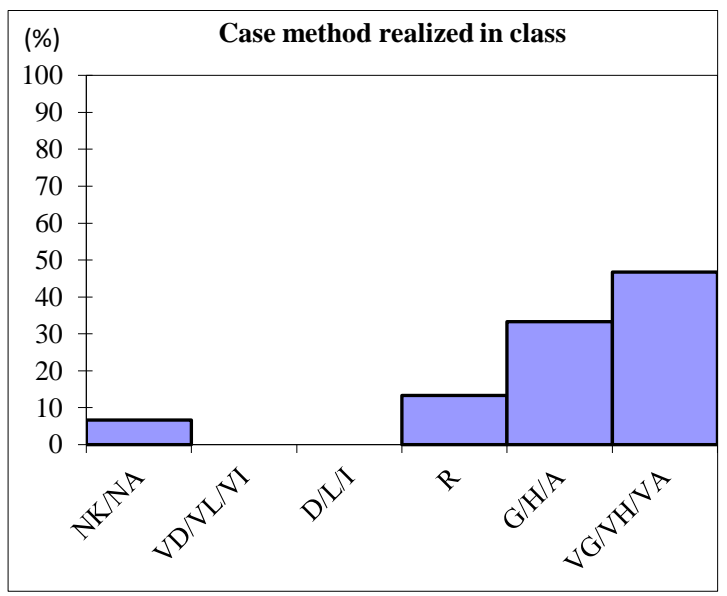

Fig. 1 Results of the opinion polls of the students about the case method realized in class in the subject of "Manufacturing Processes of Building Materials" in the 2018-2019 academic year (NK/NA: do not known/no answer; VD/VL/VI: very deficient/very low/very inadequate; D/L/I: deficient/low/inadequate; R: regular, G/H/A: good/high/adequate; VG/VH/VA: very good/very high/very adequate) (author own elaboration).

The item about the case method realized in class obtains a mark of 7.83 with a standard deviation of 1.82, which indicates high grade of satisfaction of the students.

\subsection{Autoevaluation of the lecturer}

The experience about the use of the case method in class is very positive. The case method is an useful tool for the student and the lecturer. From the student perspective, the case method permits that the students know real situations that they could find in a professional future, which increase the motivation towards the subject of study.

In addition, from the lecturer perspective, the case method allows to apply a teachinglearning methodology for the study of a real problem, as it is the corrosion of the materials, 
in order to obtain more active learning of the students. It also allows the lecturer to use a rubric as evaluation tool so that students can know the criteria with which they will be evaluated.

As a proposal for improvement for future courses, a short student poll could be carried out at the end of the activity to know if the case method is an effective way to increase student motivation and participation. It could be realized using the tool of "sondeos" in the elearning platform PoliformaT.

\section{Conclusions}

The present work describes the application of the case method as teaching-learning methodology for the study of a corrosion problem in the subject of "Manufacturing Processes of Building Materials" in the 2018/2019 academic year. The activity consists in the description by the lecturer of a real situation about a corrosion problem, so that the students can analyze it and propose solutions individually and in group. This activity is realized in class, which is evaluated using a rubric. The results show the high scores obtained by the students in the case method and the high grade of satisfaction of the students after applying the educational innovation. The case method permits that the students know real situations that they could find in a professional future, which increase the motivation towards the subject of study.

\section{Acknowledgments}

Authors would like to express their gratitude to the project PIME: Aprendizaje Basado en Problemas para su aplicación en las áreas de Ingeniería Química y de Materiales (Ref. 27) and to the Instituto de Ciencias de la Educación and the Vicerrectorado de Estudios, Calidad y Acreditación from the Universitat Politècnica de Valencia, for their financial and technical support.

\section{References}

Bain, K (2005). Lo que hacen los mejores profesores universitarios. Publicacions de la Universitat de València.

Labrador, M.J., Andreu, M.A., González-Escrivá J.A. (2008). Método del caso. In Labrador M.J., Andreu M.A. (Ed.), Metodologías activas (pp. 25-41). Valencia: Editorial de la Universitat Politècnica de València. 
López, A. (1997). Iniciación al análisis de casos, una metodología activa de aprendizaje en grupos. Bilbao: Ediciones Mensajero.

Vázquez, G. (1995). El estudio de casos como estrategia formativa en la pedagogía universitaria y en la pedagogía laboral. In López-Barajas, E., Montoya, M. (Ed.), El estudio de casos: fundamentos y metodología (pp. 31-41). Madrid: UNED.

Wassermann, S. (1994). El estudio de casos como método de enseñanza. Buenos Aires: Amorrortu editores. 